\title{
Hydrogen Peroxide Modulation of Synaptic Plasticity
}

\author{
Ariel Kamsler and Menahem Segal \\ Department of Neurobiology, The Weizmann Institute, Rehovot 76100, Israel
}

Unlike the proposed role of reactive oxygen species in neurodegeneration, acute effects of reactive oxygen on synaptic plasticity are poorly understood. Using rat hippocampal slices, we found that exposure to a high concentration $\left(0.5-5 \mathrm{mM}^{2}\right.$ of $\mathrm{H}_{2} \mathrm{O}_{2}$ reduces EPSPs in both potentiated and nonpotentiated synapses. Exposure of the slices to $20 \mu \mathrm{M} \mathrm{H}_{2} \mathrm{O}_{2}$ did not affect expression of preestablished long-term potentiation (LTP) but prevented induction of new LTP and enhanced long-term depression (LTD). Surprisingly, $1 \mu \mathrm{M} \mathrm{H}_{2} \mathrm{O}_{2}$ caused a twofold increase in LTP compared with controls, and it further enhanced NMDA-independent LTP. A low concentration of $\mathrm{H}_{2} \mathrm{O}_{2}$ also suppressed LTD. Nifedipine, an L-type calcium channel blocker, did not affect control LTP but blocked effects of both 1 and $20 \mu \mathrm{M} \mathrm{H}_{2} \mathrm{O}_{2}$. Calcineurin inhibitors [FK506 (FR900506) and cyclosporin A but not rapamycin] acted similarly and also restored LTP in the presence of $20 \mu \mathrm{M} \mathrm{H} \mathrm{H}_{2} \mathrm{O}_{2}$. These results suggest that $\mathrm{H}_{2} \mathrm{O}_{2}$ alters NMDA-independent, voltage-gated calcium channel-mediated LTP by activating calcineurin.

Key words: calcineurin; hippocampus; LTP; LTD; calcium; hydrogen peroxide

\section{Introduction}

Reactive oxygen species (ROS) are the byproducts of cellular metabolism that have been implicated in neurodegeneration and age-associated cognitive and memory impairments. Thus far, ROS have been treated as harmful agents that cause damage to macromolecules through nucleophillic attack (Halliwell, 1992). However, there are recent indications that ROS may have an important role as signaling molecules that are used by cells as second messengers for altering the redox state of specific molecules that affect their functions (Klann,1998; Barrett et al., 1999). These regulatory roles can only occur under physiologically significant concentrations of ROS, which are strictly regulated in vivo by a myriad of antioxidant molecules. Recently, a link between ROS and modulation of synaptic plasticity has been proposed; high concentrations of ROS attenuate synaptic transmission and long-term potentiation (LTP) (Colton et al., 1986, 1989; Pellmar et al., 1991; Avshalumov et al., 2000). They also induce stress-related responses (O'Donnell et al., 2000). On the other hand, superoxide radicals are proposed to be involved in LTP induction (Klann, 1998; Thiels et al., 2000; Knapp and Klann, 2002).

We studied effects of hydrogen peroxide $\left(\mathrm{H}_{2} \mathrm{O}_{2}\right)$, a membrane-permeable form of ROS that is normally produced in living cells, on the synapse between the Schaffer collateral projections in stratum radiatum and pyramidal cells in area CA1 of the rat hippocampus. LTP and long-term depression (LTD) of the EPSPs are valuable tools in the investigation of cellular processes affecting synaptic plasticity. These processes are induced by calcium influx through NMDA receptors but also through voltagedependent calcium channels (VDCCs) (Morgan and Teyler, 1999). The transient changes in calcium are transduced by signal

Received Jan. 25, 2002; revised 0ct. 21, 2002; accepted 0ct. 22, 2002.

This work was supported by Alzheimer's Association Grant IIRG-00-2152. We thank Shay Covo for advice regarding CaN assay.

Correspondence should be addressed to Menahem Segal, Department of Neurobiology, The Weizmann Institute, Rehovot 76100, Israel. E-mail: menahem.segal@weizmann.ac.il.

Copyright $\odot 2002$ Society for Neuroscience $0270-6474 / 02 / 220269-08 \$ 15.00 / 0$ transduction cascades, including the calcium-dependent activation of calcium calmodulin, which activates the phosphatase calcineurin (CaN) (Foster et al., 2001). These processes cause a change in the AMPA receptor functions that underlie long-term changes in EPSPs. Blockade of CaN activity with the specific inhibitor FR900506 (FK506) in the postsynaptic cell induces LTP (Wang and Kelly, 1997). On the other hand, FK506 blocks VDCC-dependent LTP (Onuma et al., 1998). These seemingly contradictory results may be explained by the observation that CaN mediates LTD of the GABAergic IPSP in the postsynaptic cells ( $\mathrm{Lu}$ et al., 2000). CaN activity is also increased in aged individuals (Foster et al., 2001), and Ermak et al. (2001) found an overexpression of a CaN inhibitory gene in brains of Alzheimer's disease patients.

We examined the effect of physiologically relevant concentrations of $\mathrm{H}_{2} \mathrm{O}_{2}$ on different measures of synaptic plasticity in the $\mathrm{CA} 1$ region of rat hippocampal slices. Subsequently, we began to elucidate the molecular sequence of events leading to these changes. These data shed new light on the understanding of redox contribution to mechanisms underlying synaptic plasticity in the hippocampus.

\section{Materials and Methods}

DL-2-Amino-5-phosphonopentanoic acid (APV), nifedipine, cyclosporin A (Cys A), and hydrogen peroxide were purchased from Sigma (St. Louis, MO). FK506 was a generous gift from Fujisawa Pharmaceuticals (Tokyo, Japan). Rapamycin was purchased from Alomone Labs (Jerusalem, Israel). Pharmaceuticals were added into the perfusion medium with special care to prevent changes in temperature, $\mathrm{pH}$, flow rate, or degree of oxygenation of the artificial CSF (ACSF).

Electrophysiology. Hippocampal slices from 6- to 8-week-old male Wistar rats were prepared as follows. After decapitation, the hippocampus was removed, and $350 \mu \mathrm{m}$ slices were made with a McIlwain tissue slicer and incubated for $1.5 \mathrm{hr}$ in ACSF containing (in mM): $124 \mathrm{NaCl}, 2$ $\mathrm{KCl}, 26 \mathrm{NaHCO}_{3}, 1.24 \mathrm{KH}_{2} \mathrm{PO}_{4}, 2.5 \mathrm{CaCl}_{2}, 2 \mathrm{MgSO}_{4}$, and 10 glucose, $\mathrm{pH}$ 7.4 , at room temperature. The ACSF was saturated with $95 \% \mathrm{O}_{2}-5 \% \mathrm{CO}_{2}$ gas mixture. After incubation, the slices were placed in a perfusion-type chamber for recording. Recordings were made with a glass pipette containing $0.75 \mathrm{M} \mathrm{NaCl}(4 \mathrm{M} \Omega)$ placed in stratum radiatum. Stimulation was 
delivered through two sets of bipolar nichrome electrodes placed on either side of the recording electrode such that two independent stimulation channels were used for each slice. Unless stated otherwise, LTP was induced by high-frequency stimulation (HFS) consisting of 100 pulses at twice the test intensity delivered at a frequency of $100 \mathrm{~Hz}$, and stimulation and data acquisition and analysis was performed using the LTP Program (Anderson and Collingridge, 2001).

Enzyme assay. Five hippocampal slices were placed in the perfusion chamber and subjected to either ACSF or ACSF containing 1 or $20 \mu \mathrm{M}$ $\mathrm{H}_{2} \mathrm{O}_{2}$. The slices were collected, washed with cold saline, and homogenized in lysis buffer supplied with the Calcineurin Assay kit (Biomol, Plymouth Meeting, PA), containing $50 \mathrm{~mm}$ Tris, pH 7.5, 0.1 mм EDTA, $0.1 \mathrm{~mm}$ EGTA, $1 \mathrm{~mm}$ DTT, and $0.2 \% \mathrm{NP}-40$. The samples were centrifuged $(100,000 \times g, 45 \mathrm{~min})$, and the supernatant was filtered through a desalting column for the removal of free phosphates. The filtered samples were incubated at $30^{\circ} \mathrm{C}$ for $5 \mathrm{~min}$ in reaction buffer from the kit with or without $0.5 \mu \mathrm{M}$ okadaic acid. The enzyme activity was expressed in nanomoles of orthophosphate $\left(\mathrm{PO}_{4}\right)$ released per milligram of protein from the substrate. The calcineurin substrate sequence is Asp-Leu-Asp-ValPro-Ile-Pro-Gly-Arg-Phe-Asp-Arg-Arg-Val-pSer-Val-Ala-Ala-Glu. The sequence is from protein kinase A regulatory subunit type II. The protein concentration was calculated using the Bradford method (Bio-Rad, Hercules, CA).

Statistical analysis was done by using one-way or two-way ANOVA, Student's $t$ test, or Mann-Whitney nonparametric test whenever relevant.

\section{Results}

\section{$\mathrm{H}_{2} \mathrm{O}_{2}$ at $20 \mu \mathrm{M}$ affects synaptic plasticity without disrupting} baseline synaptic responses

Previous studies show that $0.5-10 \mathrm{mM} \mathrm{H}_{2} \mathrm{O}_{2}$ can dramatically suppress synaptic transmission and plasticity (Colton et al., 1986, 1989; Pellmar et al., 1991; Avshalumov et al., 2000). EPSP slopes shown were normalized and are expressed as a fraction of mean baseline EPSP slope. When $5 \mathrm{mM} \mathrm{H}_{2} \mathrm{O}_{2}$ was added to the perfusion medium, the magnitude of EPSP slopes declined to $0.07 \pm$ 0.07 in the previously potentiated channel and to $0.34 \pm 0.2$ in the nonpotentiated channel $(n=4)$. This decline in EPSP magnitude began 2-3 min after addition of $\mathrm{H}_{2} \mathrm{O}_{2}$ to the perfusing medium (Fig. 1A). The rapid decline in EPSP slope preceded a slower decline in the magnitude of the presynaptic volley, which was associated with an irreversible decline in slice viability.

Exposure of the slices to $0.5 \mathrm{mM} \mathrm{H}_{2} \mathrm{O}_{2}$ (Fig. $1 \mathrm{~B}$ ) did not change basal EPSP slope; however, preestablished LTP declined from $1.48 \pm 0.0410 \mathrm{~min}$ after HFS to $1.02 \pm 0.0715 \mathrm{~min}$ after addition of $\mathrm{H}_{2} \mathrm{O}_{2}(t=7.24 ; p<0.0001 ; n=7)$. HFS that was applied in the presence of $0.5 \mathrm{mM} \mathrm{H}_{2} \mathrm{O}_{2}$ resulted in EPSP slope that was $1.11 \pm$ 0.08 of control 15 min after HFS $(t=5.72 ; p<0.0001 ; n=7)$.

In the presence of $20 \mu \mathrm{M} \mathrm{H}_{2} \mathrm{O}_{2}$ applied for $10 \mathrm{~min}$ (Fig. 1C), there was no change in EPSP slope $(0.98 \pm 0.06)$. LTP that was induced before $\mathrm{H}_{2} \mathrm{O}_{2}$ perfusion remained at $1.6 \pm 0.12$, indicating that this concentration of $\mathrm{H}_{2} \mathrm{O}_{2}$ did not affect the ability to express larger and already potentiated EPSPs. HFS delivered in the presence of $20 \mu \mathrm{M} \mathrm{H}_{2} \mathrm{O}_{2}$ resulted in significantly reduced $(t=$ 4.18; $p<0.001)$ potentiation to $1.18 \pm 0.0420 \mathrm{~min}$ after HFS $(n=6)$.

\section{$\mathrm{H}_{2} \mathrm{O}_{2}$ at $1 \mu \mathrm{M}$ enhances LTP}

To determine the threshold of $\mathrm{H}_{2} \mathrm{O}_{2}$ effects on LTP, the tissue was exposed to lower concentrations of $\mathrm{H}_{2} \mathrm{O}_{2}$. Exposure to $<20 \mu \mathrm{M}$ of $\mathrm{H}_{2} \mathrm{O}_{2}$ did not produce a reliable blockade of LTP. In the presence of $1 \mu \mathrm{M} \mathrm{H}_{2} \mathrm{O}_{2}$ perfused for $10 \mathrm{~min}$, EPSP slope was $1.02 \pm 0.06$. EPSP slope of the pathway that was potentiated by HFS before the addition of $\mathrm{H}_{2} \mathrm{O}_{2}$ was $1.48 \pm 0.1210 \mathrm{~min}$ after the addition of $\mathrm{H}_{2} \mathrm{O}_{2}$. Surprisingly, HFS applied $10 \mathrm{~min}$ after the addition of 1 $\mu \mathrm{M} \mathrm{H}_{2} \mathrm{O}_{2}$ resulted in EPSP slope that was $1.99 \pm 0.1620 \mathrm{~min}$ after
A
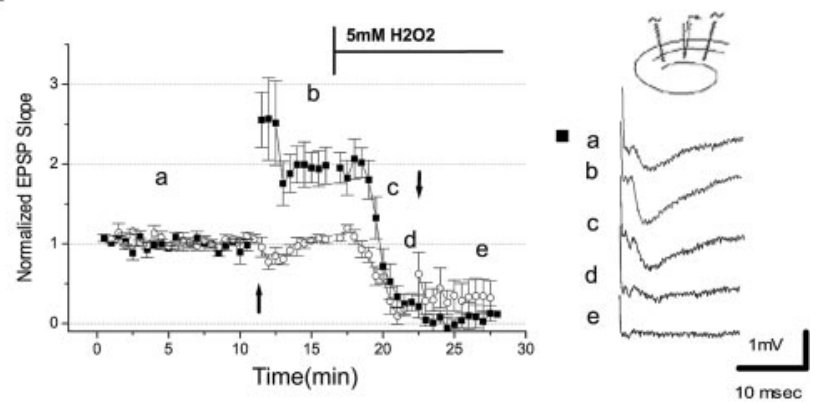

B
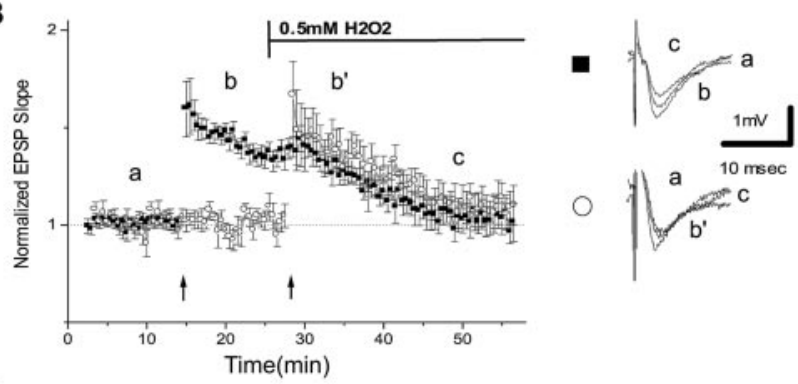

C

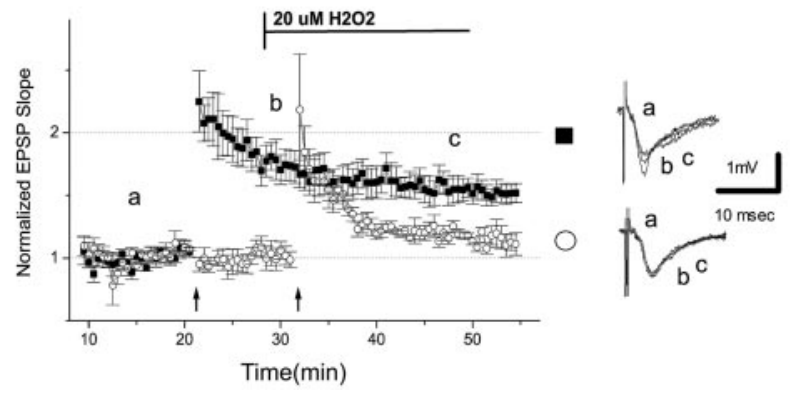

Figure 1. Long-term potentiation is inhibited by hydrogen peroxide. A, Application of $5 \mathrm{~mm}$ $\mathrm{H}_{2} \mathrm{O}_{2}$ (bar) depresses EPSP magnitude in both potentiated $(\square)$ and unpotentiated $(\bigcirc)$ pathways. Schematic presentation of the two channels is in the inset on the right. Average normalized EPSP slope is plotted versus time. In the right, $a-e$ are representative tracings at indicated times. The arrows indicate the time of application of HFS ( $100 \mathrm{~Hz}$ for $1 \mathrm{sec}$ at twice the test stimulus intensity). $B$, Application of $0.5 \mathrm{~mm} \mathrm{H}_{2} \mathrm{O}_{2}$ causes a decrease in EPSP amplitude of the potentiated channel $(\mathbf{\square})$, which declines $15 \mathrm{~min}$ after $\mathrm{H}_{2} \mathrm{O}_{2}$ application. This concentration of $\mathrm{H}_{2} \mathrm{O}_{2}$ also prevents the induction of new LTP in the previously unpotentiated channel $(O) . \mathrm{C}$, Application of $20 \mu \mathrm{M} \mathrm{H}_{2} \mathrm{O}_{2}$ does not affect the potentiated pathway; it does, however, inhibit the induction of new LTP in the previously unpotentiated pathway. ( $a-c$ on the right correspond to the position of the EPSP peak.)

HFS ( $n=10$ ), which is a statistically significant (ANOVA; $p<$ 0.05 ) twofold increase in LTP compared with the pathway that was potentiated before the addition of $1 \mu \mathrm{M} \mathrm{H}_{2} \mathrm{O}_{2}$ (Fig. $2 \mathrm{~A}$ ).

To establish that this increase was within normal physiological range and not a result of $\mathrm{H}_{2} \mathrm{O}_{2}$ causing hyperexcitability of the slice, more rigorous stimulation protocols were used before addition of $\mathrm{H}_{2} \mathrm{O}_{2}$. Three trains of HFS $2.5 \mathrm{~min}$ apart resulted in EPSP slope that was $2.16 \pm 0.220 \mathrm{~min}$ after the last train. This potentiation was not significantly different from that induced in the same slices in the presence of $1 \mu \mathrm{M} \mathrm{H}_{2} \mathrm{O}_{2}$ (Fig. $2 \mathrm{~B}$ ), which resulted in EPSP slope that was $1.95 \pm 0.32,20 \mathrm{~min}$ after the single HFS train $(n=20)$. This indicates that the enhanced LTP by $\mathrm{H}_{2} \mathrm{O}_{2}$ saturates at the level reached by the multiple trains of HFS.

Finally, in the presence of $0.1 \mu \mathrm{M} \mathrm{H}_{2} \mathrm{O}_{2}$, the EPSP slope was $1.66 \pm 0.1315$ at minutes after HFS. This potentiation was not significantly different from that induced before the addition of $0.1 \mu \mathrm{M} \mathrm{H}_{2} \mathrm{O}_{2}$, which resulted in EPSP slopes that were $1.83 \pm 0.15$ 
A
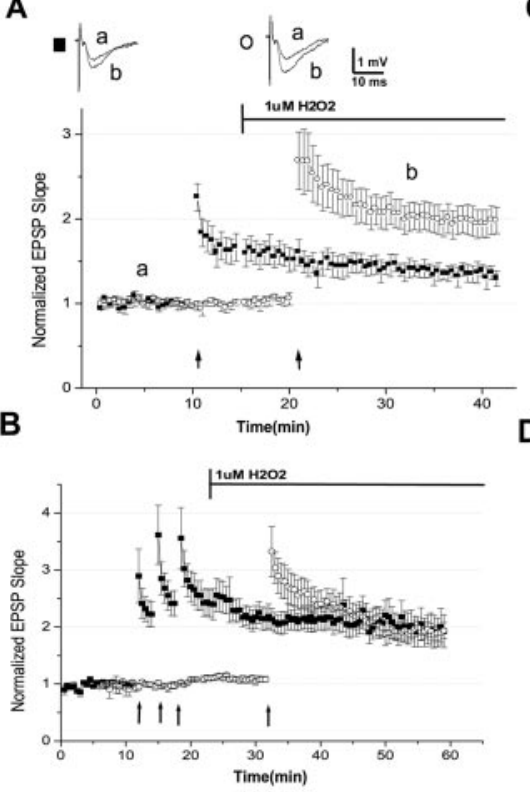

C
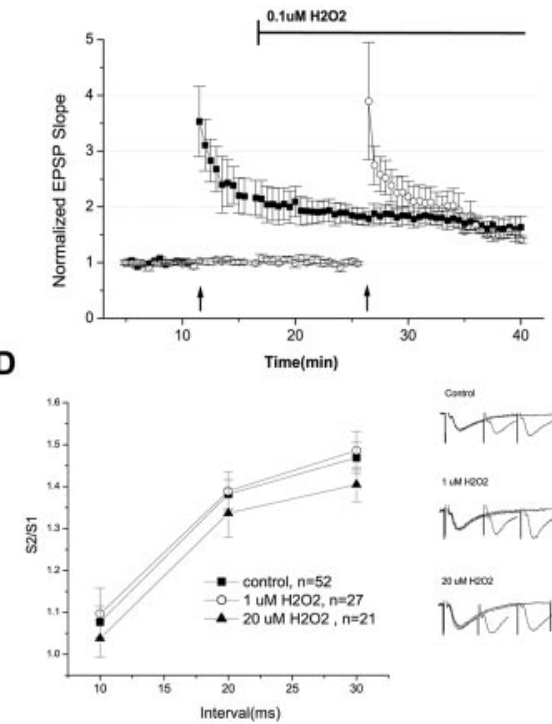

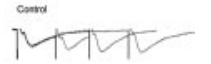

twisece

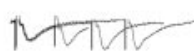

sow

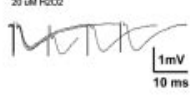

Figure 2. Lower concentrations of $\mathrm{H}_{2} \mathrm{O}_{2}$ have opposing effects on LTP. A, Application of $1 \mu \mathrm{m} \mathrm{H}_{2} \mathrm{O}_{2}$ (bar) increases LTP levels by twofold compared with control. HFS applied in the same slices before $\mathrm{H}_{2} \mathrm{O}_{2}(\square)$ resulted in a normal LTP, whereas HFS applied 10 min after addition of $\mathrm{H}_{2} \mathrm{O}_{2}(\bigcirc)$ resulted in a significantly larger LTP. In the top, $a$ and $b$ are representative tracings at indicated times. $B$, Application of multiple trains of HFS resulted in LTP that is similar in size to LTP induced by one HFS train in the presence of $1 \mu \mathrm{M} \mathrm{H}_{2} \mathrm{O}_{2}$. HFS was applied three times with an intertrain interval of $2.5 \mathrm{~min}$ on one channel ( $\square$ ). A single train of HFS was applied to the second channel (O) 10 min after onset of infusion of $1 \mu \mathrm{M} \mathrm{H}_{2} \mathrm{O}_{2}$ (bar). C, Application of $0.1 \mu \mathrm{m} \mathrm{H} \mathrm{H}_{2}$ does not affect LTP. LTP induced before $(\square)$ and $10 \mathrm{~min}$ after $(\bigcirc)$ the application of $0.1 \mu \mathrm{m} \mathrm{H}_{2} \mathrm{O}_{2}$ (bar) resulted in similar potentiation. $D$, Paired-pulse potentiation is not significantly altered by micromolar concentrations of hydrogen peroxide. The ratio of the second EPSP slope to the first is plotted as a function of the interval between them. In the right are representative traces of the data summarized on the left.

with exposure to a medium containing 1 or $20 \mu \mathrm{M} \mathrm{H}_{2} \mathrm{O}_{2}$ (Fig. 4). Under control conditions, $0.5 \mathrm{~Hz}$ stimulation depressed EPSP slopes to $0.79 \pm 0.08$ at 15 min after stimulation $(n=6), 5 \mathrm{~Hz}$ resulted in EPSP slopes that were not different from controls $(0.97 \pm 0.03 ; n=6)$, whereas $100 \mathrm{~Hz}$ stimulation potentiated EPSP slopes to $1.54 \pm 0.14(n=6)$. In the presence of 20 $\mu \mathrm{M} \mathrm{H}_{2} \mathrm{O}_{2} 0.5 \mathrm{~Hz}$ stimulation depressed EPSP slopes to $0.8 \pm 0.06(n=6), 5 \mathrm{~Hz}$ also depressed EPSP slopes to $0.77 \pm 0.06$ $(n=6)$, thus expanding LTD to frequencies that do not produce it in the control case, whereas $100 \mathrm{~Hz}$ stimulation potentiated EPSP slopes only to $1.2 \pm 0.2(n=6)$.

In the presence of $1 \mu \mathrm{M} \mathrm{H} \mathrm{H}_{2} \mathrm{O}_{2}, 0.5 \mathrm{~Hz}$ stimulation failed to cause depression of EPSP slopes, and they were $1.03 \pm 0.08$ at 15 min after stimulation $(n=6) ; 5 \mathrm{~Hz}$ stimulation resulted in EPSP slopes that were $0.99 \pm 0.05(n=6)$, whereas $100 \mathrm{~Hz}$ potentiated EPSP slopes to $2.12 \pm 0.16$ of controls $(n=6)$. Two-way ANOVA shows a significant variation attributable to stimulation frequency $(p<0.001)$ and also $\mathrm{H}_{2} \mathrm{O}_{2}$ concentration $(p<0.005)$.

Together, these findings demonstrate that $\mathrm{H}_{2} \mathrm{O}_{2}$ affects hippocampal plasticity in a concentration- and frequencydependent manner. at 15 min after the HFS (Fig. $2 C)(n=5)$. Thus, $0.1 \mu \mathrm{M} \mathrm{H}_{2} \mathrm{O}_{2}$ did not seem to affect the plastic properties of the slice.

Changes in LTP can result from either presynaptic change in probability of release or postsynaptic changes in the response to the tetanic stimulation. To examine a possible presynaptic locus of action, paired-pulse stimulation protocol was used (Fig. 2D). Under control conditions, two pulses, at 10, 20, and $30 \mathrm{msec}$ interpulse intervals, resulted in a second EPSP that was $1.08 \pm$ $0.03,1.38 \pm 0.03$, and $1.47 \pm 0.04$ of the first pulse, respectively. In the presence of $1 \mu \mathrm{M} \mathrm{H}_{2} \mathrm{O}_{2}$, the values were $1.09 \pm 0.06,1.39 \pm$ 0.04 , and $1.48 \pm 0.04$, respectively. In the presence of $20 \mu \mathrm{M}$ $\mathrm{H}_{2} \mathrm{O}_{2}$, the comparative values were $1.03 \pm 0.04,1.33 \pm 0.05$, and $1.40 \pm 0.04$. There was no significant difference among the treatments. In addition, the size of the presynaptic volley did not change with either 1 or $20 \mu \mathrm{M} \mathrm{H}_{2} \mathrm{O}_{2}$ or after HFS (Figs. 1C, $2 \mathrm{~A}$ ). These experiments indicate that the effects of $\mathrm{H}_{2} \mathrm{O}_{2}$ are not likely to take place presynaptically at the Schaffer collateral fibers and terminals.

Because the EPSP evoked in response to afferent stimulation is mediated primarily by activation of the AMPA receptor and there was no effect of $\mathrm{H}_{2} \mathrm{O}_{2}$ on EPSP, it is still possible that these effects are mediated by an interaction with the NMDA receptor, normally inactive at rest attributable to an $\mathrm{Mg}^{2+}$ block. To examine the effect of $\mathrm{H}_{2} \mathrm{O}_{2}$ on NMDAR EPSPs, slices were perfused with magnesium-free ACSF and in the presence of $10 \mu \mathrm{M}$ glycine and $10 \mu \mathrm{M}$ DNQX, an AMPA receptor antagonist. The addition of 1 or $20 \mu \mathrm{M} \mathrm{H}_{2} \mathrm{O}_{2}$ did not change NMDA EPSPs (Fig. 3).

\section{$\mathrm{H}_{2} \mathrm{O}_{2}$ affects both LTP and LTD}

To test the possibility that $\mathrm{H}_{2} \mathrm{O}_{2}$ shifts the optimal response to different stimulation frequencies, they were tested in conjunction

\section{The enhancement of LTP by $1 \mu \mathrm{M} \mathrm{H}_{2} \mathrm{O}_{2}$ is mediated by activation of VDCCs}

In addition to NMDA receptors, calcium ions can permeate the membrane through VDCCs. These channels increase permeability to calcium when the neuronal membrane is depolarized during the EPSP. VDCC are assumed to be activated by higherstimulation frequencies than those activating NMDA receptors (Morgan and Teyler, 1999). Because the effects of $1 \mu \mathrm{M} \mathrm{H} \mathrm{H}_{2} \mathrm{O}_{2}$ could be reproduced by using multiple trains of stimulation (Fig. 2 ), the possible mediation of the effects of $1 \mu \mathrm{M} \mathrm{H} \mathrm{H}_{2} \mathrm{O}_{2}$ by activation of VDCC was tested using nifedipine $(50 \mu \mathrm{M})$, a specific L-type VDCC blocker. Nifedipine by itself did not affect EPSPs or LTP under control conditions (Fig. 5A). EPSPs that had been already potentiated before exposure to nifedipine were $1.5 \pm 0.11$ of controls at $20 \mathrm{~min}$ after HFS compared with those potentiated after the addition of nifedipine, which were $1.49 \pm 0.07(n=6)$. However, in the presence of nifedipine, $1 \mu \mathrm{M} \mathrm{H}_{2} \mathrm{O}_{2}$ could no longer potentiate EPSP slope in response to HFS beyond the control level. EPSP slopes potentiated in the presence of $1 \mu \mathrm{M}$ $\mathrm{H}_{2} \mathrm{O}_{2}$ before addition of nifedipine were $2.1 \pm 0.09$ at $20 \mathrm{~min}$ after HFS compared with those potentiated after the addition of nifedipine, which were $1.49 \pm 0.06$ (Fig. $5 B)(n=9)$. Interestingly, nifedipine could not reverse the suppressive action of 20 $\mu \mathrm{M} \mathrm{H}_{2} \mathrm{O}_{2}$ on LTP (data not shown). However, nifedipine abolished LTD at $20 \mathrm{~min}$ after $5 \mathrm{~Hz}$ stimulation down to $0.98 \pm 0.07$ $(n=6)$ (see Fig. $7 B)$.

To further establish a connection between the effect of $1 \mu \mathrm{M}$ $\mathrm{H}_{2} \mathrm{O}_{2}$ on LTP and VDCCs, we induced non-NMDA LTP in the presence of APV. LTP can still be induced in the presence of APV by three $200 \mathrm{~Hz}$ trains (Fig. 5C). EPSP slopes in these conditions 
were $1.5 \pm 0.12$ of control at 25 min after stimulation. In the presence of $1 \mu \mathrm{M}$ $\mathrm{H}_{2} \mathrm{O}_{2}$, EPSP slopes were $2.8 \pm 0.3$ of control at 25 min after stimulation $(n=7)$. These experiments indicate that NMDA receptors are not required for the potentiation induced by $1 \mu \mathrm{M} \mathrm{H}_{2} \mathrm{O}_{2}$ and that blocking VDCCs eliminated this effect.

Calcineurin mediates the changes in synaptic plasticity induced by $20 \mu \mathrm{M} \mathrm{H} \mathrm{H}_{2} \mathrm{O}_{2}$ Synaptic plasticity is assumed to be regulated through a balance between phosphorylation-dephosphorylation of ion channels. This balance is maintained by kinases and phosphatases, respectively. The phosphatase CaN has been found to be high in older animals that exhibit less LTP and more LTD (Foster et al., 2001). CaN has a redox-sensitive domain (Wang et al., 1996), which can be affected by $\mathrm{H}_{2} \mathrm{O}_{2}$ and can change the activity of the enzyme.

We tried to reverse the changes in plasticity seen with $\mathrm{H}_{2} \mathrm{O}_{2}$ by inhibiting $\mathrm{CaN}$ activity. To this end, the specific $\mathrm{CaN}$ inhibitors FK506 ( $n=6$ slices) and Cys A ( $n=7$ slices) were used. LTP was not altered by the presence of $20 \mu \mathrm{M}$ FK506 (Fig. $6 A$ ). EPSP slopes in the presence of FK506 were $1.64 \pm 0.07$ of controls when measured $20 \mathrm{~min}$ after HFS, which was not significantly different from EPSP slopes of a second channel in the same slices in which HFS was induced before FK506 perfusion (1.7 \pm 0.15). Perfusing FK506 or Cys A before the addition of $20 \mu \mathrm{M}$ $\mathrm{H}_{2} \mathrm{O}_{2}$ resulted in a return of LTP back to control levels, with EPSP slopes being $1.87 \pm 0.18$ and $1.52 \pm 0.11(n=6)$, respectively (Fig. $6 B, D$ ), compared with 20

$\mu \mathrm{M} \mathrm{H}_{2} \mathrm{O}_{2}$ alone, which resulted in EPSP slopes of $1.2 \pm 0.05(n=$ 5) of controls.

Furthermore, perfusing FK506 or Cys A before the addition of $1 \mu \mathrm{M} \mathrm{H}_{2} \mathrm{O}_{2}$ resulted in a decrease in LTP; EPSP slopes were $1.65 \pm$ 0.17 and $1.7 \pm 0.2(n=7)$, respectively (Fig. $6 C, D)$. These, again, were not different from untreated controls compared with $1 \mu \mathrm{M}$ $\mathrm{H}_{2} \mathrm{O}_{2}$ alone, which resulted in EPSP slopes $1.99 \pm 0.16(n=11)$.

The response to $5 \mathrm{~Hz}$ stimulation was not altered by the presence of FK506 (Fig. 7A). Under control conditions, EPSP slopes were $0.94 \pm 0.06$ at $20 \mathrm{~min}$ after $5 \mathrm{~Hz}$ stimulation $(n=10)$ and $0.93 \pm 0.01$ in the presence of FK506 $(n=10)$. Stimulation at 5 $\mathrm{Hz}$ in the presence of $20 \mu \mathrm{M} \mathrm{H}_{2} \mathrm{O}_{2}$ resulted in EPSP slopes that were depressed to $0.77 \pm 0.04$ of control at $20 \mathrm{~min}$ after $5 \mathrm{~Hz}$ stimulation. FK506 and Cys A were also effective in reducing LTD in the presence of $20 \mu \mathrm{M} \mathrm{H}_{2} \mathrm{O}_{2}$. Perfusing FK506 or Cys A before addition of $20 \mu \mathrm{M} \mathrm{H}_{2} \mathrm{O}_{2}$ resulted in a decrease in the response to $5 \mathrm{~Hz}$ stimulation; EPSP slopes were $0.98 \pm 0.05$ and $0.96 \pm 0.01$ at $20 \mathrm{~min}$ after $5 \mathrm{~Hz}$ stimulation, respectively (Fig. $7 C, D)(n=7)$. These experiments suggest that redox-regulated CaN activity underlies the plasticity changes seen with $\mathrm{H}_{2} \mathrm{O}_{2}$.

FK506 inhibits calcineurin by binding to FK506 binding pro-
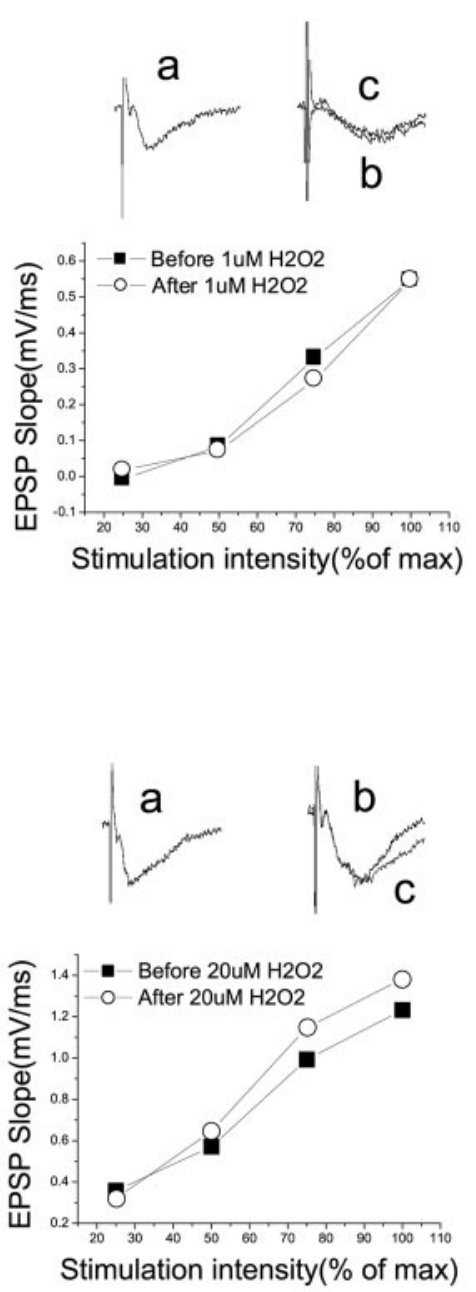

Time(min)

Figure 3. Micromolar concentrations of $\mathrm{H}_{2} \mathrm{O}_{2}$ do not change NMDA receptor function. $A$, Hippocampal slices were placed in a right, $a-$ care sample traces taken at the times indicated on the left. At the bottom right are input- output curves for NMDA receptor EPSP slopes before and after the addition of $\mathrm{H}_{2} \mathrm{O}_{2}$. $\mathrm{B}$, Similar to $A$ but with $20 \mu \mathrm{M} \mathrm{H}_{2} \mathrm{O}_{2}$.

tein 12 (FKBP-12) and forming a complex that inhibits CaN. To better define the underlying process, we added rapamycin to the perfusion medium. Rapamycin binds FKBP-12, but the complex formed does not interact with CaN. Rapamycin alone did not affect LTP, and HFS in the presence of rapamycin resulted in potentiation to $1.48 \pm 0.07$ of control at 20 min after HFS ( $n=$ 12). In the presence of $20 \mu \mathrm{M} \mathrm{H}_{2} \mathrm{O}_{2}$ and rapamycin, potentiation was down to $1.18 \pm 0.08$ of control, showing no interaction between rapamycin and $20 \mu \mathrm{M} \mathrm{H}_{2} \mathrm{O}_{2}(n=9)$. Interestingly, perfusion of rapamycin with $1 \mu \mathrm{M} \mathrm{H}_{2} \mathrm{O}_{2}$ resulted in no LTP (EPSP slope, $1.04 \pm 0.04 ; n=12$ ) (Fig. 8 ). These findings suggest that different mechanisms underlie the effects mediated by 1 and 20 $\mu \mathrm{M} \mathrm{H}_{2} \mathrm{O}_{2}$.

To find more direct evidence connecting $\mathrm{H}_{2} \mathrm{O}_{2}$ with $\mathrm{CaN}$, we conducted an enzymatic assay. Hippocampal slices were perfused with ACSF containing $\mathrm{H}_{2} \mathrm{O}_{2}$, collected, and homogenized. The centrifuged supernatants were passed through a desalting column, and the phosphate-free samples were measured for phosphatase activity (Fig. 9). Phosphatase activity was also measured in the presence of $0.5 \mu \mathrm{M}$ okadaic acid, which inhibits protein phosphatase 1 (PP1) and PP2A, resulting in net CaN activity. To 
A

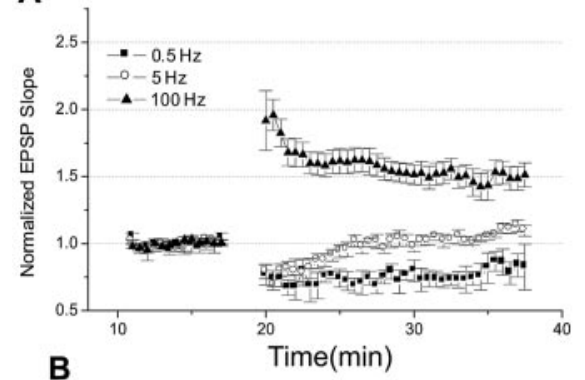

B

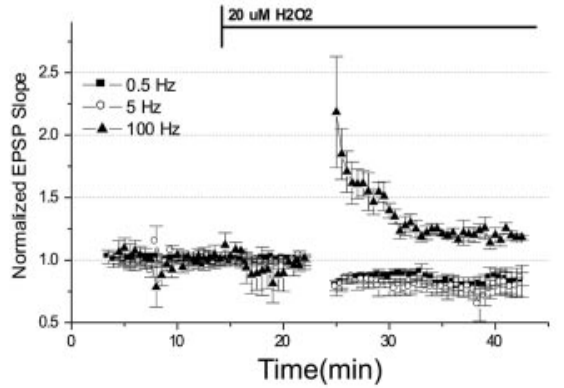

C
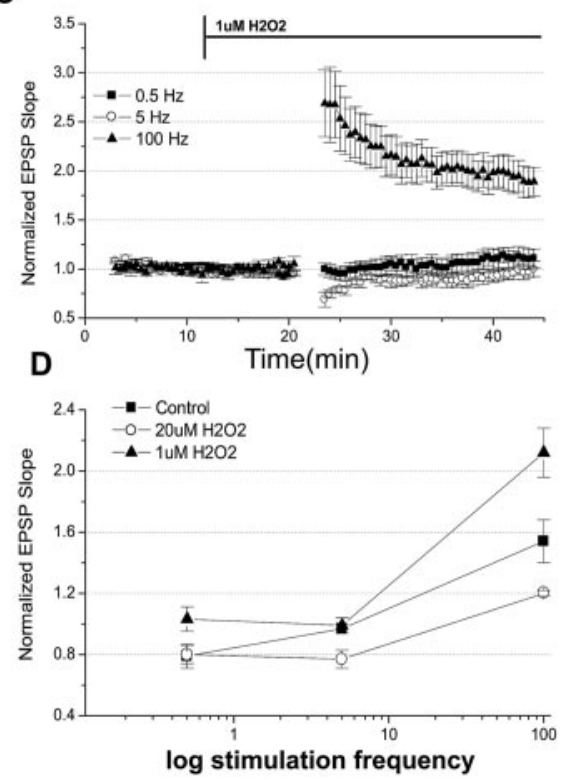

Figure 4. Micromolar concentrations of hydrogen peroxide affect both LTP and LTD. A, Under control conditions, a train of pulses at the frequency of $0.5 \mathrm{~Hz}$ results in LTD, stimulation with a $5 \mathrm{~Hz}$ train does not have an affect, and stimulation at $100 \mathrm{~Hz}$ results in LTP. $B$, When $20 \mathrm{M} \mathrm{H}_{2} \mathrm{O}_{2}$ was added, a train of pulses at the frequency of $0.5 \mathrm{~Hz}$ resulted in LTD, stimulation with a $5 \mathrm{~Hz}$ train also caused LTD, and stimulation at $100 \mathrm{~Hz}$ caused reduced LTP. C, When $1 \mu \mathrm{m} \mathrm{H} \mathrm{H}_{2}$ was added, a train of pulses at the frequency of $0.5 \mathrm{~Hz}$ did not induce LTD, stimulation with a $5 \mathrm{~Hz}$ train, similarly, did not have an effect, and stimulation at $100 \mathrm{~Hz}$ induced large LTP. D, The graph summarizes the data shown in $A-C$. The normalized EPSP slope at $15 \mathrm{~min}$ after the application of a train of pulses is plotted as a function of stimulation frequency (log scale) for the two concentrations of $\mathrm{H}_{2} \mathrm{O}_{2}$.

achieve maximal validity, we conducted two sets of experiments in triplicate. Because incubation time with the substrate and temperature can affect the amount of free phosphate that is detected, we normalized the results as a fraction of the results obtained for the controls. The overall serine-threonine phosphatase activity can be the result of CaN activity, as well as that of PP1 and PP2A, which are inhibited by okadaic acid. We found a slight increase in total phosphatase activity in slices incubated with $20 \mu \mathrm{M} \mathrm{H} \mathrm{H}_{2} \mathrm{O}_{2}$ and a nonsignificant increase in specific $\mathrm{CaN}$ activity in slices incubated with $1 \mu \mathrm{M} \mathrm{H}_{2} \mathrm{O}_{2}$. A significant (42\%; Mann-Whitney $U$ test; $p<0.04)$ increase was seen in the okadaic acid-treated homogenate of slices treated with $20 \mu \mathrm{M} \mathrm{H}_{2} \mathrm{O}_{2}$, indicating a selective increase by hydrogen peroxide of $\mathrm{CaN}$ activity (Fig. 9).

\section{Discussion}

In previous studies (Colton et al., 1986, 1989; Pellmar et al., 1991; Avshalumov et al., 2000), LTP was found to be blocked by exposure to high concentrations of $\mathrm{H}_{2} \mathrm{O}_{2}$. Similarly high concentrations, in the millimolar range, are being used to explore the neurotoxic action of $\mathrm{H}_{2} \mathrm{O}_{2}$ in relation to neurodegenerative diseases in cell cultures and Xenopus oocytes (Li et al., 1998; Kanno et al., 1999; Yermolaieva et al., 2000; Burlacu et al., 2001; Jang and Surh, 2001; Datta et al., 2002). Although there is no direct evidence showing the amount of ROS that is actually generated in aged brains, Hyslop et al. (1995) measured $200 \mu \mathrm{M} \mathrm{H}_{2} \mathrm{O}_{2}$ in rat forebrain after ischemia using microdialysis. Although studies using $\mathrm{H}_{2} \mathrm{O}_{2}$ may provide useful information, with few exceptions (Auerbach and Segal, 1997), they are applying far higher concentrations than those seen by normal neural tissue. We found that $20 \mu \mathrm{M} \mathrm{H}_{2} \mathrm{O}_{2}$ does not affect control level of synaptic transmission and does not affect an already potentiated pathway but blocks the induction of novel LTP by HFS. This indicates that $\mathrm{H}_{2} \mathrm{O}_{2}$ inter- feres with one or more of the processes activated directly by the tetanic stimulation. This concentration also increases the range of frequencies that can induce LTD. These alterations in LTP and LTD could be reversed by pharmacological intervention, which is directed at $\mathrm{CaN}$, a protein phosphatase that was shown to take part in signal transduction events underlying synaptic plasticity that we found to be more active in slices treated with $20 \mu \mathrm{M}$ $\mathrm{H}_{2} \mathrm{O}_{2}$.

Synaptic plasticity is regulated by calcium influx into the postsynaptic cell. A "sliding rule" has been proposed to account for the fact that both LTP and LTD can be induced in the same pathway by different patterns of stimulation (Bear, 1995): low-frequency stimulation induces LTD, whereas high-frequency stimulation induces LTP. Young adult animals display both LTD and LTP with a characteristic crossing frequency of $\sim 5 \mathrm{~Hz}$. Slices taken from old rats require more severe stimulation for inducing LTP but display a larger LTD to low frequencies and a wider range of frequencies that can induce LTD. It has been suggested that aged rats are impaired in the regulation of ROS (McGahon et al., 1999; O'Donnell et al., 2000), and their brains are exposed to higher concentrations of ROS than young adults. Norris et al. (1998a) suggested a mechanism by which an increase in VDCC permeability in aged individuals results in a larger calcium flux, which in turn activates calcium-dependent potassium channels, causing a longer afterhyperpolarization (AHP). Moreover, it has been suggested (Mermelstein et al., 2000) that L-type VDCCs can act as a kinetic filter differentiating between action potentials and EPSPs causing differential phosphorylation of cAMP response element-binding protein. The longer AHP in aged rats has been associated with higher VDCC permeability (Campbell et al., 1996; Thibault et al., 2001). Calcium-gated potassium channels remain open longer in aged neurons (Moyer et al., 1992). Furthermore, nifedipine, an L-type VDCC antagonist, can reduce LTD in aged neurons (Norris et al., 1998b) in a manner similar to that mediated by the addition of apamin, a potassium channel antagonist. Calcium channels have been found on hippocampal dendrites and have been shown to be regulated by phosphorylation (Hell et al., 1995). Wang and Kelly (1997) have shown that FK506 injected postsynaptically can induce LTP, which is blocked by the addition of the calcium chelator BAPTA, indicating a postsynaptic role for CaN. Recently, Norris et al. (2002) found that CaN can enhance VDCC activity in hippocampal neurons with an increased effect in aged cultures. Shirotani et al. (2001) found that hydroxyl radicals can suppress calcium influx through VDCCs, suggesting a direct effect of ROS on VDCC.

Inactivation of $\mathrm{CaN}$ by $\mathrm{H}_{2} \mathrm{O}_{2}$ has been shown previously (Bogumil et al., 2000); however, this inactivation was demonstrated using higher concentrations than we used $(>250 \mu \mathrm{M}$ $\mathrm{H}_{2} \mathrm{O}_{2}$ ). Several studies demonstrated that even low concentrations of $\mathrm{H}_{2} \mathrm{O}_{2}$ can induce the release of calcium from internal stores (Gen et al., 2001; Nam et al., 2002), which can then affect the activation of CaN. Moreover, Huang et al. (2001) demon- 
A

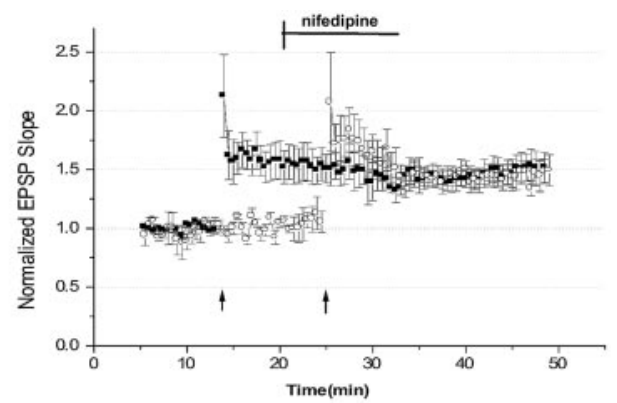

B

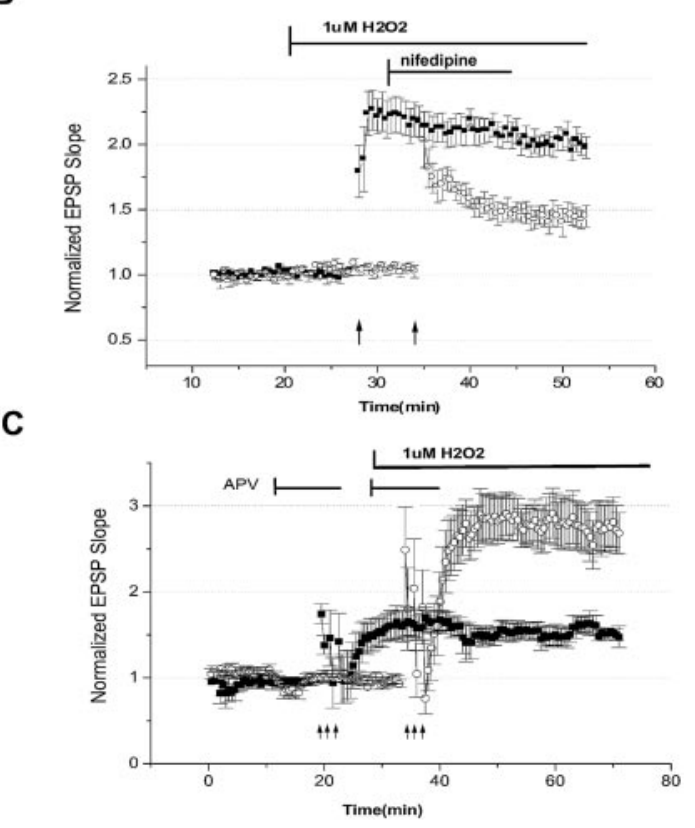

Figure 5. Potentiation of LTP modulated by $1 \mu \mathrm{M} \mathrm{H}_{2} \mathrm{O}_{2}$ is mediated through voltagedependent calcium channels. $A$, Nifedipine alone did not change LTP. After LTP was induced by HFS (arrow) in one channel ( $\square$ ), nifedipine (bar; $50 \mu \mathrm{m}$ ) was added and HFS was applied to the second channel $(\bigcirc)$, yielding similar LTP. $B$, Nifedipine dampened LTP modulation by $\mathrm{H}_{2} \mathrm{O}_{2}$. One micromolar $\mathrm{H}_{2} \mathrm{O}_{2}$ was applied for $10 \mathrm{~min}$ (long bar) before application of HFS on the first channel (ם). Nifedipine (50 $\mu \mathrm{m})$ was added $5 \mathrm{~min}$ before application of HFS on the second channel $(\bigcirc)$, resulting in a much-reduced LTP. C, The NMDA component of LTP is not required for modulation by $1 \mu \mathrm{MH}_{2} \mathrm{O}_{2}$. Non-NMDA LTP was induced in the first channel $(\square)$ by three trains of 100 pulses at the same intensity as the test pulse at $200 \mathrm{~Hz}$ (arrows) in the presence of $50 \mu \mathrm{M} \mathrm{APV} \mathrm{(bars).}$ The addition of $1 \mu \mathrm{M} \mathrm{H}_{2} \mathrm{O}_{2}$ (long bar) $10 \mathrm{~min}$ before application of the three-high frequency trains to the second channel resulted in a much larger non-NMDA LTP in that channel $(\bigcirc)$.

strated that vanadium can induce the activation of NFAT (nuclear factor of activated $\mathrm{T}$ cells), a CaN substrate, in a manner that is reversible by the addition of $\mathrm{H}_{2} \mathrm{O}_{2}$ scavengers and suggested a direct role for $\mathrm{H}_{2} \mathrm{O}_{2}$ in the activation of CaN.

Together, these studies are consistent with our observations on the effects of $20 \mu \mathrm{M} \mathrm{H} \mathrm{H}_{2} \mathrm{O}_{2}$ and suggest that a similar phenotype is found in slices taken from older rats and that the way to restore their normal function is similar, i.e., by blocking $\mathrm{CaN}$.

The effect of $1 \mu \mathrm{M} \mathrm{H} \mathrm{H}_{2}$ is more complex and less consistent with the assumed toxic action of ROS predicted in other studies. This very low concentration of $\mathrm{H}_{2} \mathrm{O}_{2}$ actually potentiates the ability to express long-lasting LTP, producing an effect similar to that seen after a strong (three times) tetanic stimulation protocol. The effect of $1 \mu \mathrm{M} \mathrm{H}_{2} \mathrm{O}_{2}$ is also blocked by $\mathrm{CaN}$ and calcium channel antagonists; however, it is completely reduced by rapamycin, indicating a different molecular mechanism from that affected by the higher concentration of $\mathrm{H}_{2} \mathrm{O}_{2}$, which may explain how the effect of the lower concentration of $\mathrm{H}_{2} \mathrm{O}_{2}$ is opposite to that of the higher concentration. Both FK506 and rapamycin act by forming a complex with FK506 binding protein 12 (FKBP-12), but, whereas the FK506-FKBP-12 complex inhibits CaN, the rapamycin-FKBP-12 does not. The binding of FKBP-12 by these agents detaches it from ryanodine receptors and facilitates the release of calcium from internal stores (Terashima et al., 2000). Moreover, the rapamycin-FKBP-12 complex, but not the FK506-FKBP-12 complex, inhibits the Ser-Thr kinase mTOR (mammalian target of rapamycin) (Huang and Houghton, 2001). Together, it is hypothesized that $1 \mu \mathrm{M} \mathrm{H}_{2} \mathrm{O}_{2}$ acts via FKBP12 , affecting internal calcium stores or kinase activity.

It may then be hypothesized that $1 \mu \mathrm{M} \mathrm{H}_{2} \mathrm{O}_{2}$ "primes" the postsynaptic neuron by activation of kinases, resulting in a larger reaction to the calcium flux induced by HFS. In that sense, our results are congruent with those of Klann (1998), who proposed that formation of ROS is a necessary phase in the formation of LTP. Subsequently, clamping down levels of endogenous $\mathrm{H}_{2} \mathrm{O}_{2}$ may reduce the ability to express LTP rather than enhance it.

Together, these findings suggest a complex modulatory role for ROS in synaptic plasticity through the activation of specific signal transduction cascades in a reversible manner.

\section{References}

Anderson WW, Collingridge GL (2001) The LTP Program: a data acquisition program for on-line analysis of long-term potentiation and other synaptic events. J Neurosci Methods 108:71-83.

Auerbach JM, Segal M (1997) Peroxide modulation of slow onset potentiation in rat hippocampus. J Neurosci 17:8695-8701.

Avshalumov MV, Chen BT, Rice ME (2000) Mechanisms underlying $\mathrm{H}_{2} \mathrm{O}_{2}-$ mediated inhibition of synaptic transmission in rat hippocampal slices. Brain Res 882:86-94.

Barrett WC, DeGnore JP, Keng YF, Zhang ZY, Yim MB, Chock PB (1999) Roles of superoxide radical anion in signal transduction mediated by reversible regulation of protein-tyrosine phosphatase 1B. J Biol Chem 274: 34543-34546.

Bear MF (1995) Mechanism for a sliding synaptic modification threshold. Neuron 15:1-4.

Bogumil R, Namgaladze D, Schaarschmidt D, Schmachtel T, Hellstern S, Mutzel R, Ullrich V (2000) Inactivation of calcineurin by hydrogen peroxide and phenylarsine oxide. Evidence for a dithiol-disulfide equilibrium and implications for redox regulation Eur $\mathrm{J}$ Biochem 267:1407-1415.

Burlacu A, Jinga V, Gafencu AV, Simionescu M (2001) Severity of oxidative stress generates different mechanisms of endothelial cell death. Cell Tissue Res 306:409-416.

Campbell LW, Hao SY, Thibault O, Blalock EM, Landfield PW (1996) Aging changes in voltage-gated calcium currents in hippocampal CA1 neurons. J Neurosci 16:6286-6295.

Colton CA, Colton JS, Gilbert DL (1986) Changes in synaptic transmission produced by hydrogen peroxide. J Free Radic Biol Med 2:141-148.

Colton CA, Fagni L, Gilbert D (1989) The action of hydrogen peroxide on paired pulse and long-term potentiation in the hippocampus. Free Radic Biol Med 7:3-8.

Datta K, Babbar P, Sriyastava T, Sinha S, Chattopadhyay P (2002) p53 dependent apoptosis in glioma cell lines in response to hydrogen peroxide induced oxidative stress. Int J Biochem Cell Biol 34:148-157.

Ermak G, Morgan TE, Davies KJ (2001) Chronic overexpression of the calcineurin inhibitory gene DSCR1 (Adapt78) is associated with Alzheimer's disease. J Biol Chem 276:38787-38794.

Foster TC, Sharrow KM, Masse JR, Norris CM, Kumar A (2001) Calcineurin links $\mathrm{Ca}^{2+}$ dysregulation with brain aging. J Neurosci 21:4066-4073.

Gen W, Tani M, Takeshita J, Ebihara Y, Tamaki K (2001) Mechanisms of $\mathrm{Ca}^{2+}$ overload induced by extracellular $\mathrm{H} 2 \mathrm{O} 2$ in quiescent isolated rat cardiomyocytes. Basic Res Cardiol 96:623-629.

Halliwell B (1992) Reactive oxygen species and the central nervous system. J Neurochem 59:1609-1623.

Hell JW, Yokoyama CT, Breeze LJ, Chavkin C, Catterall WA (1995) Phos- 
A

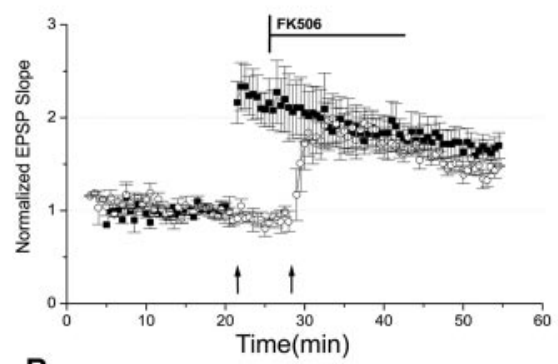

B

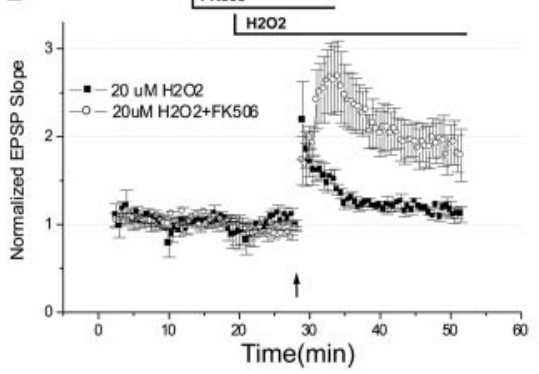

C

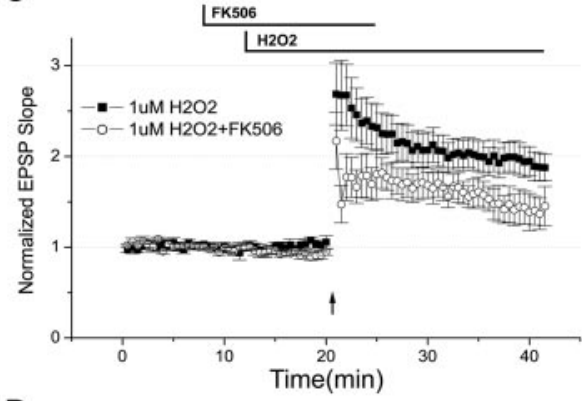

D

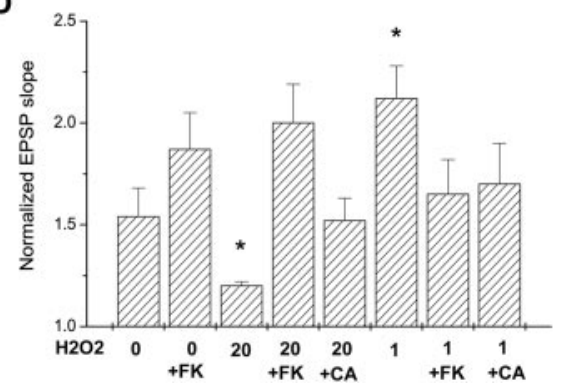

Figure 6. Inhibitors of calcineurin reverse the effects of micromolar concentrations of $\mathrm{H}_{2} \mathrm{O}_{2}$ on LTP. A, FK506 alone does not change LTP. After the induction of LTP by HFS (arrow) in one channel $(\square)$, FK506 (bar; $20 \mu \mathrm{M})$ was added and HFS was applied to the second channel, yielding similar LTP. B, FK506 restores LTP in slices treated with $20 \mu \mathrm{M} \mathrm{H}_{2} \mathrm{O}_{2}$. EPSP slopes for different sets of slices treated with either $20 \mu \mathrm{m} \mathrm{H} \mathrm{H}_{2}$ alone $(\square)$ or $20 \mu \mathrm{MH}_{2} \mathrm{O}_{2}$ and $20 \mu \mathrm{m} \mathrm{FK506} \mathrm{(O).} \mathrm{C,} \mathrm{FK506} \mathrm{suppresses} \mathrm{LTP} \mathrm{in} \mathrm{slices} \mathrm{treated} \mathrm{with}$

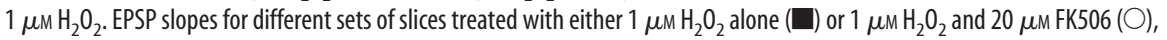
indicating that FK506 dampens the enhancing effect of $1 \mu \mathrm{M} \mathrm{H}_{2} \mathrm{O}_{2}$ on LTP. D, Summary results of the effects of both FK506 (FK) and cyclosporin $\mathrm{A}(\mathrm{CA})$ to reverse the action of micromolar concentrations of $\mathrm{H}_{2} \mathrm{O}_{2}$ on LTP. The normalized EPSP slope 15 min after HFS is shown for the various treatments.
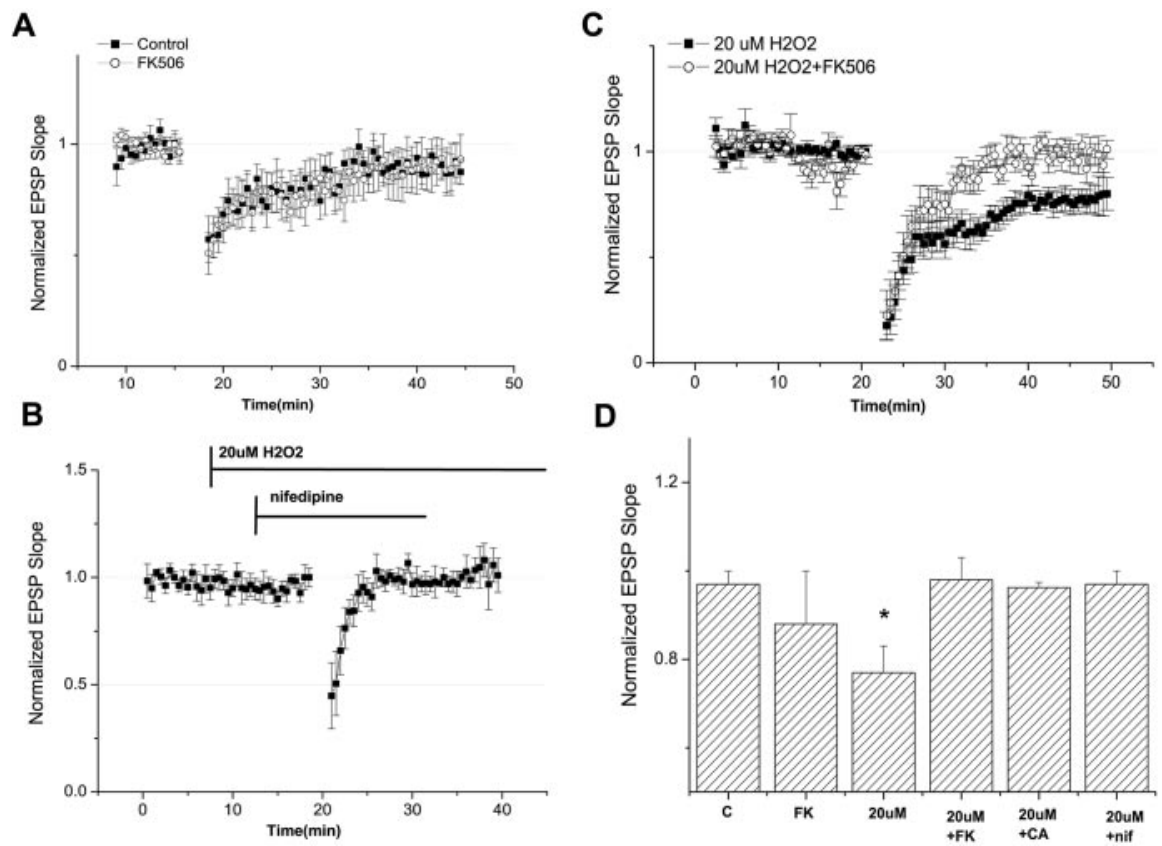

Figure 7. Inhibitors of calcineurin and VDCC reverse the effects of $20 \mu \mathrm{M} \mathrm{H} \mathrm{H}_{2}$ on LTD. A, FK506 alone does not facilitate LTD after $5 \mathrm{~Hz}$ stimulation. EPSP slopes for control slices $(\square)$ or for slices treated with $20 \mu \mathrm{m}$ FK506 $(\bigcirc)$ virtually overlap. B, Nifedipine prevents LTD induced by $5 \mathrm{~Hz}$ low-frequency stimulation in the presence of $20 \mathrm{Mm} \mathrm{H}_{2} \mathrm{O}_{2} \cdot \mathrm{H}_{2} \mathrm{O}_{2}$ at $20 \mu \mathrm{m}$ was applied for $10 \mathrm{~min}$ (Iong bar) before application of low-frequency stimulation, and nifedipine ( $50 \mu \mathrm{M})$ was added 5 min before application of LFS. C, FK506 blocks the LTD produced in response to a $5 \mathrm{~Hz}$ stimulation in presence of $20 \mathrm{M} \mathrm{H}_{2} \mathrm{O}_{2}$. Averaged EPSP slopes for separate sets of slices treated with $20 \mu \mathrm{M} \mathrm{H}_{2} \mathrm{O}_{2}$ alone $(\square)$ or with $20 \mu \mathrm{M} \mathrm{H} \mathrm{O}_{2}$ and $20 \mu \mathrm{m}$ FK506 (O). D, FK506 (FK), cyclosporin A (CA), and nifedipine (nif) reverse the effects of $20 \mu \mathrm{m} \mathrm{H}_{2} \mathrm{O}_{2}$ on LTD. The normalized EPSP slope at 15 min after low-frequency stimulation is shown for the various treatments.

phorylation of presynaptic and postsynaptic calcium channels by cAMP dependent protein kinase in hippocampal neurons. EMBO J 14:3036-3044.

Huang C, Ding M, Li J, Leonard SS, Rojanasakul Y, Castranova V, Vallyathan V, Ju G, Shi X (2001) Vanadium-induced nuclear factor of activated T cells activation through hydrogen peroxide. J Biol Chem. 276:22397-22403.

Huang S, Houghton PJ (2001) Mechanisms of resistance to rapamycins. Drug Resist Updat 4:378-391.

Hyslop PA, Zhang Z, Pearson DV, Phebus LA (1995) Measurement of striatal $\mathrm{H} 2 \mathrm{O} 2$ by microdialysis following global forebrain ischemia and reperfusion in the rat: correlation with the cytotoxic potential of $\mathrm{H} 2 \mathrm{O} 2$ in vitro. Brain Res 671:181-186.

Jang JH, Surh YJ (2001) Protective effects of resveratrol on hydrogen peroxide-induced apoptosis in rat pheochromocytoma (PC12) cells. Mutat Res 496:181-190.

Kanno S, Ishikawa M, Takayanagi M, Takayanagi Y, Sasaki K (1999) Exposure to hydrogen peroxide induces cell death via apoptosis in primary cultured mouse hepatocytes. Biol Pharm Bull 22:1296-1300.

Klann E (1998) Cell-permeable scavengers of superoxide prevent long-term potentiation in hippocampal area CA1. J Neurophysiol 80:452-457.

Knapp LT, Klann E (2002) Potentiation of hippocampal synaptic transmission by superoxide requires the oxidative activation of protein kinase C. J Neurosci 22:674-683.

Li A, Segui J, Heinemann SH, Hoshi T (1998) Oxidation regulates cloned neuronal voltagedependent $\mathrm{Ca}^{2+}$ channels expressed in Xenopus oocytes. J Neurosci 18:6740-6747.

Lu YM, Mansuy IM, Kandel ER, Roder J (2000) Calcineurin-mediated LTD of GABAergic inhibition underlies the increased excitability of CA1 neurons associated with LTP. Neuron 26: 197-205.

McGahon BM, Martin DS, Horrobin DF, Lynch MA (1999) Age-related changes in synaptic function: analysis of the effect of dietary supplementation with omega- 3 fatty acids. Neuroscience 94:305-314.

Mermelstein PG, Bito H, Deisseroth K, Tsien RW (2000) Critical dependence of cAMP response element-binding protein phosphorylation on L-type calcium channels supports a selective response to EPSPs in preference to action potentials. J Neurosci 20:266-273.

Morgan SL, Teyler TJ (1999) VDCCs and NMDARs underlie two forms of LTP in CA1 hippocampus in vivo. J Neurophysiol 82:736-740.

Moyer Jr JR, Thompson LT, Black JP, Disterhoft JF (1992) Nimodipine increases excitability of rabbit CA1 pyramidal neurons in an ageand concentration-dependent manner. J Neurophysiol 68:2100-2109.

Nam SH, Jung SY, Yoo CM, Ahn EH, Suh CK (2002) $\mathrm{H} 2 \mathrm{O} 2$ enhances $\mathrm{Ca}^{2+}$ release from osteoblast internal stores. Yonsei Med J 43:229-235.

Norris CM, Halpain S, Foster TC (1998a) Reversal of age-related alterations in synaptic plasticity by blockade of L-type $\mathrm{Ca}^{2+}$ channels. J Neurosci 18:3171-3179.

Norris CM, Halpain S, Foster TC (1998b) Alter- 


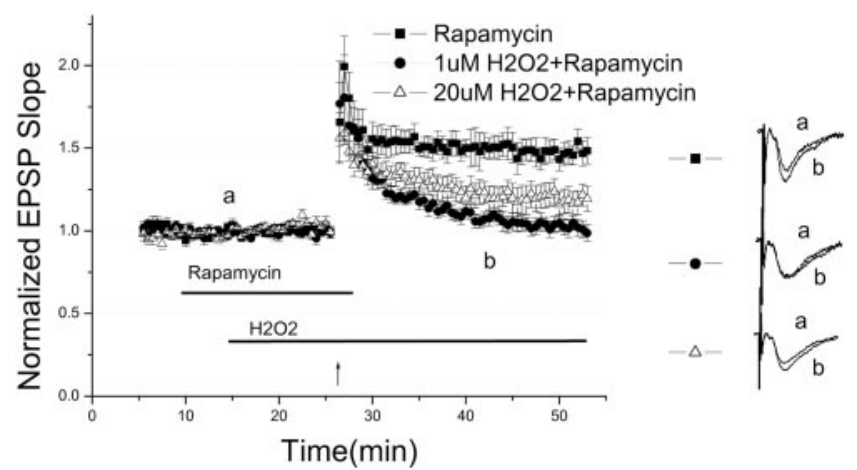

Figure 8. Rapamycin blocks the effect of $1 \mu \mathrm{M} \mathrm{H}_{2} \mathrm{O}_{2}$ but not that of $20 \mu \mathrm{MH}_{2} \mathrm{O}_{2}$ on LTP. Slices were exposed to different concentrations of $\mathrm{H}_{2} \mathrm{O}_{2}$ after preincubation with rapamycin. Rapamycin has no effect on LTP under control conditions (control records not shown). In the presence of $20 \mu \mathrm{MH}_{2} \mathrm{O}_{2}$, LTP was reduced as before. Surprisingly, in the presence of $1 \mu \mathrm{MH}_{2} \mathrm{O}_{2}$, rapamycin completely suppressed formation of LTP. On the right are representative traces at the time points indicated.

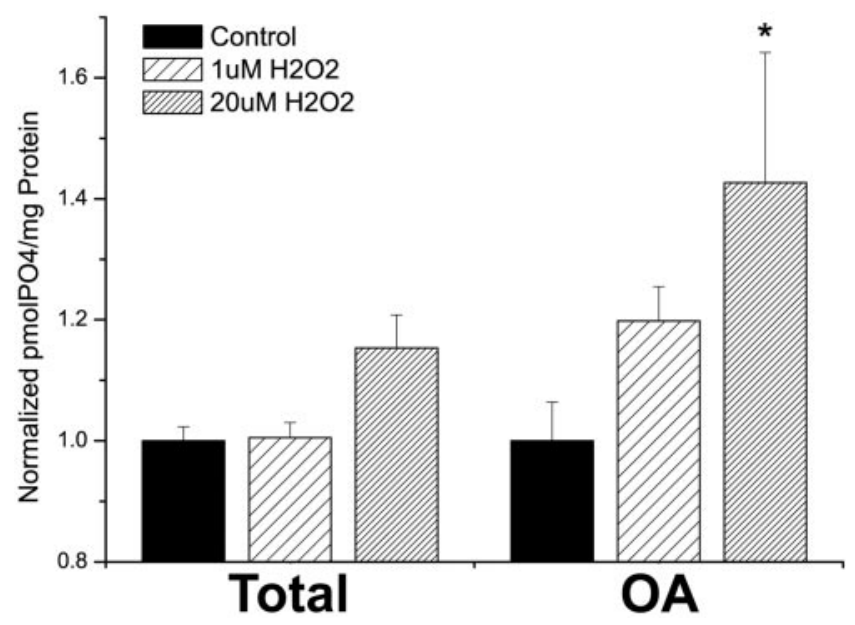

Figure 9. Micromolar concentrations of $\mathrm{H}_{2} \mathrm{O}_{2}$ enhance the activity of CaN. Hippocampal slices (5 in each group) were incubated with different concentrations of $\mathrm{H}_{2} \mathrm{O}_{2}$, homogenized, and centrifuged. The supernatant was passed through a desalting column, the extract was incubated with Ser-Thr phosphatase substrate, and the released P04 was detected with the Biomol Green reagent. The total phosphatase activity is presented in the left columns, and the specific activity of $\mathrm{CaN}$ in the presence of okadaic acid $(O A)$, which inhibits other phosphatases (PP1 and PP2A), is presented in the right columns. Four to five measurements were pooled, and the results are expressed as a fraction of the phosphatase activity under control conditions. Statistical significance is indicated with an asterisk. ations in the balance of protein kinase/phosphatase activities parallel reduced synaptic strength during aging. J Neurophysiol 80:1567-1570.

Norris CM, Blalock EM, Chen KC, Porter NM, Landfield PW (2002) Calcineurin enhances L-type $\mathrm{Ca}^{2+}$ channel activity in hippocampal neurons: increased effect with age in culture. Neuroscience 110:213-225.

O'Donnell E, Vereker E, Lynch MA (2000) Age-related impairment in LTP is accompanied by enhanced activity of stress-activated protein kinases: analysis of underlying mechanisms. Eur J Neurosci 12:345-352.

Onuma H, Lu YF, Tomizawa K, Moriwaki A, Tokuda M, Hatase O, Matsui H (1998) A calcineurin inhibitor, FK506, blocks voltage-gated calcium channel-dependent LTP in the hippocampus. Neurosci Res 30:313-319.

Pellmar TC, Hollinden GE, Sarvey JM (1991) Free radicals accelerate the decay of long-term potentiation in field CAl of guinea-pig hippocampus. Neuroscience 44:353-359.

Shirotani K, Katsura M, Higo A, Takesue M, Mohri Y, Shuto K, Tarumi C, Ohkuma S (2001) Suppression of $\mathrm{Ca}^{2+}$ influx through L-type voltagedependent calcium channels by hydroxyl radical in mouse cerebral cortical neurons. Brain Res Mol Brain Res 92:12-18.

Terashima A, Taniguchi T, Nakai M, Yasuda M, Kawamata T, Tanaka C (2000) Rapamycin and FK506 induce long-term potentiation by pairing stimulation via an intracellular $\mathrm{Ca}^{2+}$ signaling mechanism in rat hippocampal CA1 neurons. Neuropharmacology 39:1920-1928.

Thibault O, Hadley R, Landfield PW (2001) Elevated postsynaptic $\left[\mathrm{Ca}^{2+}\right]_{\mathrm{i}}$ and L-type calcium channel activity in aged hippocampal neurons: relationship to impaired synaptic plasticity. J Neurosci 21:9744-9756.

Thiels E, Urban NN, Gonzalez-Burgos GR, Kanterewicz BI, Barrionuevo G, Chu CT, Oury TD, Klann E (2000) Impairment of long-term potentiation and associative memory in mice that overexpress extracellular superoxide dismutase. J Neurosci 20:7631-7639.

Wang JH, Kelly PT (1997) Postsynaptic calcineurin activity downregulates synaptic transmission by weakening intracellular $\mathrm{Ca}^{2+}$ signaling mechanisms in hippocampal CA1 neurons. J Neurosci 17:4600-4611.

Wang X, Culotta VC, Klee CB (1996) Superoxide dismutase protects calcineurin from inactivation. Nature 383:434-437.

Yermolaieva O, Brot N, Weissbach H, Heinemann SH, Hoshi T (2000) Reactive oxygen species and nitric oxide mediate plasticity of neuronal calcium signaling. Proc Natl Acad Sci USA 97:448-453. 